\title{
Self-Management and Nationalism
}

\author{
Richarda Triaprila Watiputri ${ }^{1}$, Jorden Garnaut ${ }^{2}$, Luqita Romaisyah ${ }^{3}$, Indrawati Yuhertiana ${ }^{4}$, Dwi \\ Suhartini $^{5}$ \\ \{luqitaromaisyah26@gmail.com ${ }^{3}$ \} \\ Universitas Pembangunan Nasional "Veteran” Jawa Timur, Indonesia ${ }^{1,3,4,5}$, \\ Murdoch University, Indonesia ${ }^{2}$
}

\begin{abstract}
Self management means putting everything regularly in life, in the use of time, choices, interests, activities, and in physical and mental balance. It also means the ability to encourage ourself to progress, regulate all personal elements, and develop various aspects of personal life to achieve the desired goals. Self-management can support the inculcation of nationalism in every individual by enabling them to think logically and creatively in order to be able to filter the inclusion of new things that can threaten the existence of nation. By implementing the concept of self-management, youth are expected to be able to improve their quality, because the existence of a nation is strongly influenced by the quality of the human resources that manage the nation. This research is a literature review, which reviewed and examined 6 books and 6 articles that relevant to this topic.
\end{abstract}

Keywords: self management, youth, national defense

\section{Introduction}

The country as an organization that protects people in a region, certainly faces various problems that can threaten its sovereignty. Therefore, we need an action of every citizen to maintain the sovereignty of the country, which is known as national defense. In Indonesia, the obligation of national defense is regulated in the 1945 Constitution article 27 paragraph 3 which states that "every citizen has the right and obligation to participate in national defense". In this context, national defense can be carried out physically or non-physically. Physical national defense means the struggle of citizens by using weapons to face the attacks that threaten national sovereignty. While non-physical national defense can be interpreted as an effort to protect the national sovereignty by increasing nationalism.

National defense can be realized by increasing the national progress, through education, moral and social development, and also improving public welfare, because the existence of a nation is largely determined by the quality of its people. Every individual, as the smallest level of society, have to be able to perform self-management properly to maximize their potential to support the improvement of the society's quality. Self management means putting everything regularly in life, in the use of time, choices, interests, activities, and in physical and mental balance. It also means 
the ability to encourage ourself to progress, regulate all personal elements, and develop various aspects of personal life to achieve the desired goals [1].

The ability of self-management absolutely have to be possessed by youth as the next generation who are responsible for the future of their nation, especially in this globalization era. The rapid development of information technology in this globalization era not only brings positive impacts, but also negative impacts that can threaten the existence of a nation. The existence of mobile phone which is claimed to be one of the greatest inventions of this century is one of the proofs. Various features presented by mobile phone provide a lot of convenience for daily life, especially in terms of communication and access to information. On the other hand, the easy access to information via mobile phones has several negative impacts, such as the easy spread of hoaxes, the rise of online bullying cases, and various other problems that can trigger social conflicts. For this reason, good self-management ability is needed to minimize these negative impacts.

\section{Research Methods}

This research is a literature review, which use the youth as the main object of analysis by examining and writing the results of literature review related to national defense as the national idealism. This study aims to solve actual and past problems, by collecting, compiling, clarifying, and analyzing the data. This research used textual and phenomenological approaches by seeing and analyzing the phenomena that occur among youth. As a literature review, this research reviewed and examined 6 books and 6 articles that relevant to this topic.

\section{Result and Discussion}

\section{Self Management in Youth}

Self-management is the responsible attitude to all of their behavior to be more independent and capable to predict their future [2] [3] [4]. This process is done by changing the self totality, from intellectual, emotional, spiritual, and physical aspects to achieve the desired goals [5] which involves the ability of metacognition, motivation and other active behaviors [6]. With selfmanagement, individuals can manage their personal potential, control their thoughts and speech to do the right actions in order to get a better life [7].

Self-management of youth includes at least four actions [7]: self-motivation, self-organization, self-control, and self-development. The implementation of the self-management concept can encourage a person to achieve their independence by placing everything appropriately to maximize their potential. Related to nationalism concept, the ability of self-management is important to be owned by youth as the next generation of the nation because of their responsibilities and important roles in the existence of the country [8].

\section{Implementation of Self-Management in Youth}

The first form of self-management action is self-motivation [7], an inner encouragement to carry out various activities to achieve the desired goals. Inner motivation will be stronger than motivation from the surrounding environment, so the activities can be carried out optimally. With 
self-motivation, youth can maximize their ability to achieve success which can affect the confidence level and enthusiasm to achieve further success.

The second form is self-organization, the optimal arrangement of thoughts, energy, time, place, objects, and other resources in life to achieve personal efficiency. Personal efficiency is the ability to carry out every activity properly and appropriately to get the desired results. Self-organization is planning, organizing, and taking care of all personal matters so that it takes place in an orderly manner.

Third, self-control, is fostering determination to discipline desires, stimulate enthusiasm, erode reluctance, and exert energy to achieve life goals. By implementing good self-control, youth can avoid negative things that can hinder the achievement of their goals and become a superior person.

The last form of self-management action is self-development, perfecting or enhancing abilities in variety ways, including intelligence of mind, character, personality, sense of community and personal health. Self-motivation, self-organization, and self-control aim to form and develop good behaviors in youth.

\section{Self-Management of Youth in the National Defense}

Information openness in this globalization era has a major impact on youth. Access to information through internet technology that is easily carried out by all groups triggers the tendency of youth, who are in the process of searching for identity, to imitate foreign cultures that come in Indonesia without adjusting to the national characteristics. For example, Instagram makes youth tend to spend most of their time to looking at Instagram and ignoring the more useful things that should be done. Worse, Instagram sometimes becomes a media for hoaxes deployment, hate speech, online bullying, and other things that can cause social conflicts. Thus, good selfmanagement ability is needed to minimize the negative impact of information opennes and make it useful to maintain the national integrity.

Self-management can be interpreted as an ability to control feelings, emotions and daily activities, which will affect personal life. In the study of psychology, a more appropriate concept to describe self-management, namely self-regulation [9]. This description is based on two things. First, humans can think and regulate their own behavior, so their behavior is not only influenced by the environment. Second, self-regulation is a strategy used by individuals in achieving certain goals, then humans will use certain strategies in their self-regulation. The ability of self-regulation is owned by every human being and needs to be developed and directed, because the behavior produced by self-regulation cannot arise naturally [10].

The application of good self-management can motivate ourself well, and change many aspects of life to be more efficient and optimal [11]. Youth with the ability of self-management will be able to motivate themselves to do things well and correctly, efficiently all the resources they have to achieve good goals, control themselves from things that can hinder the achievement of their goals, and develop themselves to be more quality. Youth are expected to be able to implement the concept of good self-management in their daily life as a contribution in national defense.

National defense is the attitude and actions of citizens based on a sense of patriotism, national awareness, belief in Pancasila as a national ideology, willingness to sacrifice in facing any threats, challenges, obstacles and disturbances that endanger the existence of the nation and the state, territorial integrity, and values of the Pancasila and the 1945 Constitution [12]. Self-management can support the inculcation of nationalism in every individual by enabling them to think logically 
and creatively in order to be able to filter the inclusion of new things that can threaten the existence of nation. By implementing the concept of self-management, youth are expected to be able to improve their quality, because the existence of a nation is strongly influenced by the quality of the human resources that manage the nation.

\section{Acknowledgement}

The completion of this undertaking could not have been possible without the participation and assistance of so many people whose names may not all be enumerated. Their contributions are sincerely appreciated and gratefully acknowledged. To all relatives, friends, and others who in one way or another shared their support, either morally, financially and physically, thank you. Above all, to the Great Almighty, the author of knowledge and wisdom, for this countless love. We thank you.

\section{References}

[1] G. L. Stewart, S. H. Courtright, and C. C. Manz, "Self-leadership: A multilevel review," J. Manage., vol. 37, no. 1, pp. 185-222, 2011.

[2] H. B. Uno, Orientasi Baru dalam Psikologi Pembelajaran. Jakarta: Bumi Aksara, 2008.

[3] S. Soekadji, Modifikasi Perilaku: Penerapan Sehari-hari dan Penerapan Profesional. Yogyakarta: Liberty, 1983.

[4] W. H. Cormier and L. S. Cormier, Interviewing Strategies for Helpers: Fundamental Skill Cognitive Behavioral Intervensions. Monterey, California: Brooks/Cole Publishing Company, 1985.

[5] K. Breevaart, A. B. Bakker, and E. Demerouti, "Daily Self-Management and Employee Work Engagement," J. Vocat. Behav., vol. 84, no. 1, pp. 31-38, 2014.

[6] M. N. Ghufron and R. Risnawita, Teori-Teori Psikologi. 2011.

[7] T. L. Gie, Cara Belajar yang Efisien. Yogyakarta: Liberty, 1995.

[8] L. Rosen and A. Samuel, "Managing Yourself Conquering Digital Distraction," Harv. Bus. Rev., vol. 93, no. 6, pp. 110-113, 2015.

[9] A. Bandura, "Social Cognitive Theory of Self-Regulation," Organ. Behav. Hum. Decis. Process., vol. 50, no. 2, pp. 248-287, 1991.

[10] J. E. Ormrod, Psikologi Pendidikan Membantu Siswa Tumbuh dan Berkembang. Edisi Keenam. Jakarta: Erlangga, 2008.

[11] M. Alam, A. Gale, M. Brown, and A. I. Khan, "The Importance of Human Skills in Project Management Professional Development," Int. J. Manag. Proj. Bus., vol. 3, no. 3, pp. 495$516,2010$.

[12] S. Widodo, "Implementasi Bela Negara Untuk Mewujudkan Nasionalisme," J. Ilm. Civ., vol. 1, no. 1, pp. 18-31, 2011. 